\title{
TOWARDS A WARLESS WORLD: ONE LEGAL FORMULA TO ACHIEVE TRANSITION
}

\author{
RICHARD A. FALK + \& SAUL H. MENDLOVITZ
}

\section{From a War System to a Peace System in the Contemporary World}

It is possible for jurists to work meaningfully towards the creation of a warless world-a world in which nations have neither the instruments nor the inclination to resolve their disputes by recourse to force. Creative theorizing in the recent literature of international relations ${ }^{1}$ has deepened our understanding of the central events in the international arena. Such theorizing continues to have its influence upon officials entrusted with the formation of defense and foreign policy. ${ }^{2}$ Systems analysis, game theory, conflict resolution studies, operations research, content analysis, and equilibrium approaches have emerged to supplement, if not supplant the stock repertory of the theorist of world affairs: power politics, historical exposition and national interest. ${ }^{3}$ This article is concerned with one crucial focus for future investigation by these diverse methodologies-what are the techniques that could most effectively be used to shift the pattern of inter-state relations from a dominantly threat and war system to a dominantly reconciliation and peace system ? ${ }^{4}$ In

$\dagger$ Associate Professor of International Law, Woodrow Wilson School of Public and International Affairs; Associate Professor, Princeton University.

FProfessor of Law, Law School, Rutgers University.

1. A particularly useful survey of contemporary theorizing is INTERNATIONAL. Politics and Foreign Policy; A Reader in Research and Theory (Rosenatu ed. 1961). See also Contenrporary Theory in International Relations (Hoffmann ed. 1960); The International System, Theoretical Essays (Knorr \& Verba ed. 1961).

2. For a popular presentation of this influence see Kraft, War Thinkers, Esquire, Sept. 1962, p. 102.

3. Among the many works that have had this effect are Kaplan, Systemr and Process in International Politics (1957); Rapoport, Fights, Games, and Debates (1960); Schelitng, The Strategy of Conflict (1960); SNyder, Deterrence and Defense (1961); Boulding, Conflict and Defense (1962); Deciston-miaking as an Approach to the Study of International Poltrics (Snyder, Bruck \& Sapin eds. 1962); Liska, International Eguilibrium (1957); McDougal \& Associates, Studies in World Public Order (1960); McDougat \& Feltciano, LaW and Mrnimum World Public Order (1961); McDougar \& Burke, The Public Order of the Oceans (1962); Visscher, Theory and Reality in Public International Law (Corbett transl. 1957).

4. This question highlights the quest for a political response that is adequate to cope with the widely perceived need "to do something" about the advent of nuclear technology. The prevailing interpretation of the imperative "do something" is very disappointing in view of the dangers of nuclear war. By asking the transition question we imply that to do something means to conceive and work toward a system change. This way of putting the issue states the order of magnitude of the challenge. It can not be met by reformist 
the past, efforts to answer this question have failed to take account of the strong grip of present actualities upon human and national behavior. How to acknowledge reality and yet encourage movement towards a better future is the challenging problem which prompts our focus upon transition techniques in the effort to establish a warless world. The present situation makes it clear that thermonuclear war is capable of producing unprecedented and irreparable disaster, mutilating the achievements of centuries. Consequently, a premium is to be placed upon the avoidance of any situation with a high potentiality for escalation into a cold war crisis. But almost any use of armed force between states and even some uses of armed force within states contains dangers of thermonuclear escalation. ${ }^{6}$ In this context, every possibility for initiating the process of transition from a war system to a peace system must be explored. ${ }^{7}$

There is a growing literature on how a warless world would operate, if one is created, despite the persistence of hostility and conflict. ${ }^{8}$ The project of achieving a warless world has been withdrawn from the realm of fancy. The fabric of domestic and international society which supports the war-system has now become a prominent focus for investigation. ${ }^{9}$ This new concern acknowledges the fact that previously too little attention has been given to the political and social implications of the abolition of war, and too little thinking has been done about establishing noncoercive means for achieving fundamental

thinking, although perhaps the dangers can be reduced and postponed. No solution strikes us as responsive that does not reorganize power in such a way that wars and their threat by nation against nation are no longer a characteristic mode of interaction between the basic political units in world affairs, whether this unit is a bloc, a region, or a nation.

5. We wish to stress the focus intended by the word "transition." This means a fundamental reorganization of power and value by the movement from one system to another. The notion is succinctly expressed in Boulding, The Prevention of World War III, 38 VA. L. REv. 1 (1962).

6. This altered pattern for violent conflict in world politics applies particularly to the relations of the nuclear powers. Interstate aggression may still be tenable as a way for secondary states to expand; witness, for example, the conduct of China, India (Goa), and Indonesia. For a general study of the role of law in this altered environment, see Falk, Janus Tormented: The International Law of Internal War, in TaE Internatronal. Aspects of Civil Strife (Rosenau ed., to be published).

7. The solution of the transition problem requires us to abandon the existing system for the management of political power and authority and to replace it with a new system based on a new organizing principle. Theodicy and the rule of philosopher kings were favorite solutions of the classical formulation of the transition problem in Western culture. The quest for transition is not new. See Dante, De Monarchia (Schreider tr. 1949).

8. For a group of essays dealing with facets of these problems, see Breakrmiougr to Peace (1962). See also Legal and Political Problems of World Order (Mendlovitz ed. 1962); Clark \& Sohn, World Peace Through World Law (2nd rev. ed. Clark 1960); Millis, Permanent Peace (1961); Minlis, A World Without War (1961); Millis, Order and Change in a Warless World, Saturday Review, Sept. 15, 1962, p. 18; Preventing World WAR III (Deutch, Evan \& Wright eds. 1962).

9. This is one contribution that has been definitely made by Herman Kahn's general agitation for more thinking about these "unthinkable" problems. See KА\#N, ТमINKING About the UNThinkable (1962). 
changes in a relatively unstructured social system, especially one which lacks an effective and regularly available institution that behaves like a legislative organ. ${ }^{10}$

In exploring what steps might be taken to modify or even eliminate the massive and yet delicately geared foundation that underlies the war-supporting structure, our concentration on the role to be taken by legal institutions and processes in a transition program is prompted by three general considerations. First, since an announced goal of the United States government is the establishment of peaceful world under law, ${ }^{11}$ it seems appropriate to consider its feasibility and to identify the more promising areas for movement toward it. Second, writers in international law have long provided many of the major concepts that statesmen and decision-makers use to rationalize or construct international order. ${ }^{12}$ Finally, and perhaps most importantly, whether one considers law as the primary agent or as the product of other social forces, it is clear that legal institutions and processes interact in significant fashion with all important institutions and processes of organized society. The legal order thus serves as a realistic prism for an investigation of the transition problem.

Our concern with a partial analysis of the contributions that legal method and institutions might make to the solution of the transition problems makes it necessary first to depict the wider context of world affairs within which law must operate, and then to touch upon a variety of approaches to transition that might be undertaken, either separately or simultaneously.

\section{The Context - Legal and Social}

Until recently, most respected jurists concerned with international law concentrated their attention upon the role and content of legal doctrine posited by formal lawmaking sources. ${ }^{13}$ The jurist usually was eager to de-

10. By legislative is meant the competence to generate new norms and abandon old ones to accord with shifts in social policy. The pressure for new norms, if it once is perceived as ascendant, endangers the peace of the community unless it can be satisfied. Thus it is a serious deficiency of the existing international order that it lacks a regularly operating legislative organ, especially in a period in which there is so much attention devoted to the elimination of violence from the conduct of international relations.

11. See, e.g., President Eisenhower's 1959 New Delhi speech, Single Rule of Law, in Public Papers of the Presinents of the United States: Dwight D. Eisenhower 1959, 826-32 (1959) ; and a proclamation by President Kennedy, Law Day, U.S.A.-1963, 48 Dep't State Bulz. 297 (1963).

12. See, e.g., Meeker, Role of Law in Political Aspects of World Affairs, 48 DEp'T State Bulr. 83 (1963).

13. Hence, traditional writing was quite absorbed by a discussion of rules of international law widely accepted by domestic legal orders. The extent to which the concern with sources has vanished from contemporary approaches is highlighted by the work of Myres S. McDougal. See, e.g., McDougal \& Burke, The Public Order of the Oceans (1962), where the processes associated with claims and authoritative decisions are perceived as the essential constituents of the international legal system. Good jurisprudential discussions are to be found in Gihl, The Legal Character and Sources of International Law, in Scandinatian Studies in Law $51-92$ (1957); of. Hart, The Concept of Law 208-31 (1961). 
scribe accurately and arrange logically the corpus of rules available to govern the conduct of states. The appropriateness of these scholarly emphases has been challenged because it has become increasingly evident to observers of the international scene that an understanding of legal rules depends heavily upon an awareness of the social context within which these rules are expected to function. This has persuaded some contemporary observers to insist that international law be understood in the light of the distinctive qualities possessed by existing patterns ${ }^{14}$ of international order. Among the most evident of these qualities is the decentralized distribution of power among national actors and the tendency of nations to make selfish use of their power even in the face of limiting rules. ${ }^{15}$ This datum has led the so-called "realist school"16 to assign a trivial role to law in international affairs, belittling law as pretentious and distracting rhetoric, and discounting claims that it can restrain the behavior of nations. The clash of antagonistic social orders and the arrival on the international stage of newly independent anti-colonial nations with diverse political and cultural outlooks has reinforced this negative attitude.

But even if this attitude is extreme, it cannot be doubted that the development of nuclear weapons has radically altered the climate within which international law exists. Nuclear weapons make manifest the catastrophic dangers of general war. As well, nations without significant nuclear capacity have been relegated to positions of relatively insignificant influence. Further, nuclear technology has radically undermined the state as the basic organizing unit of international affairs. The state succeeded as a mode of political organization because it, and it alone, could provide a society with security against external aggression. Now, with the possible exception of the nuclear superpowers, the state has ceased to be a suitable unit for the arrangement of national security. ${ }^{\mathbf{1 7}}$ Regional security systems are coming to replace national

14. "Patterns" rather than "pattern" is a deliberate choice. It signals the pluralism of legal order on the system level and points to the relevance of sub-systems-for instance, regional, inter-governmental, and functional networks of legal rights, duties, and institutions.

15. See Corbett, Law and Society in the Relations of States 3-89 (1951); Visscher, Theory and Reality in Public Internationar Law (Corbett transl. 1957).

16. The label "realist school" has been used in the literature of international relations to refer to such writers as Hans Morgenthau and George Kennan. Their work arose as a reaction to such tendencies as the formalism of Hans Kelsen, the legalism of Quincy Wright, and the moralism of Woodrow Wilson. In contrast, these "realists" sought to emphasize power as the real determinant of international relations, deprecating the relevance of law and morals for understanding or policy. Myres McDougal might be classified as a post-realist for he takes into account the relevance of law and morals ("values") to the study of world affairs. McDougal's great contribution is to revive the study of law as an instrument for understanding any social phenomena. See, e.g., McDougal, Some Basic Theoretical Concepts About International Law: A Policy-Oriented Framework of Inquiry, 4 J. Conflict Resolution 337 (1960).

17. This position is fully developed in Herz, International Polttics in the Atominc AGE (1959). For a shorter statement see Herz, Rise and Demise of the Territorial Statc, 9 WORLD POLITICS 473 (1957). 
defense systems. Finally, the advent of the nuclear threat has tended to shift the arenas of inter-bloc violence to areas far removed from the vital centers of bloc potency. Asia, now Africa, and soon perhaps Latin America, are chosen as the locales for the most intensive international conflicts at the strategic level.

These developments suggest that a general consensus about peaceful objectives should not be allowed to obscure the fact that there are many reasons to be pessimistic about the prospects for achieving and implementing agreements among the elites of major powers as to the means of transition. Although stalemating arrangements, designed to foreclose military confrontations with high escalation potentials are quite negotiable (especially outside of Europe), ${ }^{18}$ major efforts to give structure to joint undertakings such as disarmament or compulsory processes for pacific settlement of international disputes are not making, nor are they about to make, encouraging progress. The West refuses to accept any institutional arrangement which does not include provision for adjudicative and sanctioning processes that are roughly analogous to those that operate in its major domestic societies. In addition, the United States appears to feel that its tradition of respect for law places it at a comparative disadvantage in the cold war, given Communist contempt in theory and practice for the claims of law. Thus the serious acceptance of a legal regime governing vital relations would appear to bind the West while leaving the Sino-Soviet powers free to violate inconvenient obligations. ${ }^{19} \mathrm{Cer}$ tainly Communist ideology has made rather short shrift of the restraining claims of law, and Soviet and Chinese leaders have seemed uninhibited by adverse determinations in the United Nations with respect to Korea, Hungary, Tibet, the 1961 atmospheric nuclear test series, or the non-aggressipn pacts that were supposed to have guaranteed the autonomy of the Baltic states.

The United States, however, has also demonstrated an unwillingness to constrain its behavior in accord with applicable law ${ }^{20}$ — witness, for instance,

18. E.g., Korea, Geneva Accords of 1954, and Laos neutrality protocol of 1962. For a richly documented study of the settlement of international disputes see Modelski, International Settlenent of Internal War, in InTERnational Aspects of Crvil Strife (Rosenau ed., to be published).

19. The Soviet Union has indicated an official willingness to comply with the international legal obligations which it has explicitly and specifically undertaken. See the textbook used by the Institute of Law of the Academy of Sciences of the USSR, 1957 INTERNATIONaL LAW 282; and Tunkin, Co-Existence and International Law, 95 RECUEIL DES Cours 1 (1958). Of course, the pledge to comply is quite distinct from patterns of compliance when the political pressures to violate grow strong. The United States has violated applicable legal rules under circumstances of similar cold war pressure. See Falk, American Intervention in Cuba and the Rule of Law, 22 O\#Iо ST. L.J. 546 (1961).

20. By applicable law is meant the relevant restraining limits upon national behavior as they are construed by an impartial observer. There are obvious difficulties here. Disagreements will arise about the identity and qualifications of an impartial observer. It is quite probable that impartial observers, however designated, will disagree about the restraints that are applicable to national behavior in a particular situation. Nevertheless, the idea of applicable law is useful to suggest that there is some common basis upon which 
its participation in the Guatemalan anti-Arbenz uprising, the Suez, Lebanon and U-2 incidents, and its support of the Bay of Pigs invasion. A more symmetrical disregard for law exists on the part of cold war rivals (at least on the level of practice) than is generally conceded in the West. It should be noted that a decentralized legal system can hardly expect to solicit the compliance of major participants on crucial issues when the atmosphere is dominated by conflict and distrust. Law is an energy that informs a quest for order, but it is dependent on the convergence of ethical, political, and social ordering energies to provide an infra-structure of community support. With a sense of this extra-legal context in mind, it seems sensible to make claims modest when discussing the autonomous role of law as a means to promote transition and hasten the acceptance of a warless world. ${ }^{21}$

The role of law in this kind of world is not readily apparent. Within a modern national society we rely upon institutions of control and change to reconcile social forces in conflict. Centralized institutions are automatically, if problematically, called upon to act. But the situation is radically different if the social order in question lacks adequate central institutions. How can a decentralized legal system contribute to the dissolution of fundamental tension and hostility? The challenge of this question influences our consideration of the variety of approaches that might be taken to the transition question.

\section{Existing Approaches to Transition}

In order of increasing generality, it might be said that there are five existing approaches to the transition question. Some political crises can be solved within the existing system of international order by drawing upon the arsenal of available $a d$ hoc techniques without altering existing institutions or developing new ones. These crises can be identified and classified. Many are primarily consequences and reflections of cold war tensions. Their importance derives largely from the fact that they have been accepted as symbols of the conflict between the major powers. Solutions need not be achieved within a framework of futuristic all-encompassing settlement. They can be reached without the permanent routinization of dispute settlement and conflict-prevention machinery. Cuban-American relations, the status of Communist China, the controversies over control of Korea, Iaos, and Vietnam are illustrative. Adopting this kind of category does not imply that policymakers should be discouraged from using the occasions of settlement as op-

to make distinctions between legal and illegal conduct; if this common basis is denied, then it is tantamount to a confession that there is no acceptable way to identify a violation. Legal scholars have, it is contended, an important responsibility to seek for objectivity of outlook and to serve the world community as a panel of impartial observers. The notion of "applicability" is useful to emphasize the connection that must be made between rule and act implying the intervention of human judgment.

21. Law contributes rules, institutions, and procedures for making the transition and for stabilizing it once made; thus, it moves us toward the end-in-view and helps to sustain it should it ever come into being. However, the fundamental commitments are social and political; without these the efforts of jurists are vain futilities. 
portunities to establish more enduring forms of conflict-resolving machinery. But it is clear that certain issues demand peculiarly contextual solutions because the history of their development combines with the present framework of distrust to preclude any other approach to decision-making. The international atmosphere is so inflamed by the failure to resolve these issues that settlement is required before we can expect to promote the effective growth of a centralized legal structure. ${ }^{22}$

Another technique for approaching the transition question involves the narrowing of the economic disparity between consumer-industrialized societies and the newly-developing societies. Different governments are able to tolerate different disparities in wealth among the area and population in regions under their control. A recent study suggests that ordinarily a nation can not stand more than a ratio of three to one between its richest and poorest sections. ${ }^{23}$ In a decentralized authority structure having almost instantaneous communication and very rapid transportation of men and goods of the kind now found in the world community, ratios of more than ten to one between the richest and poorest country would eventually prove disruptive, yet such ratios of disparity exist. ${ }^{24}$ How then can these instances of disruptive disparity be eliminated? Massive aid financed from resources diverted from arms production is one possibility. Other suggestions include plans to speed up the rate of capital accumulation within the developing societies in order more effectively to allocate domestic resources. These approaches might depend heavily upon legal process and structure. For one thing, it would be natural to expand gradually the use of international financial institutions.

A third approach to transition is disarmament. It is the most obvious and, if feasible, the most satisfactory way to initiate the process of establishing a warless world. It appears to be even more directly relevant to the solution of the transition problem than does the ad hoc resolution of particular crises - -even ones of such magnitude as Berlin or Formosa-since it is designed to eliminate the means of waging major war.

Fourthly, there is the possibility of increasing the responsibility of the organized world community for the solution of domestic social problems which might otherwise escalate into cold war crises or accentuate economic disparities.

Finally, there is the ideal of a centralized legal order functioning as a governmental center of world affairs. Some development of this kind is an obvious implication of the other four approaches.

22. Compare the prospects for permanent frustration of the attempts to negotiate a Berlin or German settlement, or even a stalemate, with the ability to negotiate towards a stable solution in Korea, Laos, and the Congo.

23. Comm. Economic Development, The European Conmon Market and Its Meaning to the United States 77 (1959).

For an analysis of the problems of bringing the poorer nations into the international system see Lagos, International Stratification and Underdeveioped Countries (1963).

24. For statistical presentation of existing disparities, see id. at 4-5, 18. 
From among these this article chooses for intensive treatment disarmament and the possibility of the more responsible use of existing international organizations. We thus focus initially on the disarmament effort in order to put into perspective a proposal for implementing the least widely appreciated approach to transition-international solution of domestic problems in the previolent stages.

\section{The Outlook for Comprehenstve Disarmanent}

The directness of disarmament explains why advocates of change in the international system have so often centered their attention upon it as the single important goal. And both sides in the cold war continually proclaim that there would be more, not less, security for all national societies if there were no large scale armaments on either side. Furthermore, there is a widespread awareness of what might be accomplished domestically and in foreign policy if the burden of armament could be greatly reduced.

Yet it is clear that, except for fleeting periods, neither side has exhibited much seriousness about the quest for significant disarmament. Nor has either believed that the other side has. ${ }^{25}$ This conflict between an ideal of a disarmed world and the practices of nations with respect to it, forces us to single out the problem for special consideration. For to improve world legal order it is tuecessary to exclude the infeasible and emphasize the feasible. How realistic, then, is disarmament as an approach to the problem of transition?

Disarmament is not impossible, but its prospects, in a system-transforming as distinct from a system-stabilizing sense, ${ }^{26}$ are discouraging. Certainly nations will refuse to disarm altogether at a single stroke. Bitter national rivals find and possess many reasons not to disarm in the presence of an enemy who will presumably continue to be an enemy quite far into a disarming world. It is

25. See Barnet, Who Wants Disarmanient? (1960); Becheroefer, Postwar Negotiations for Aras Control (1961) ; Spanier \& Nogee, The Politics of DisararaMent (1962); Forbes, The Strategy of Disaramament (1962).

26. Cf., e.g., sections on "Measures to Strengthen Arrangements for Keeping the Peace" in the United States proposals of 1962: Blueprint For tre PeAce RAceOutline of Basic Provisions of a Treaty on General and Conplete Disarminarent IN A Peacefur Wordd (April 18, 1962). The disarmament negotiations disclose an insistence upon forms of legal order that are transplanted from domestic legal systems. For instance, there is evident a reliance upon the International Court of Justice as an indispensable agency for dispute settlement. This is somewhat perplexing because the existence and retention of the Connally Amendment and our invocation of it in the Interhandel dispute to withdraw the case from the International Court of Justice suggest the reluctance of the United States to accept the competence of impartial international institutions, especially when the subject-matter concerns vital questions. In view of the hasty preparation of the 1962 outline of basic provisions, one wonders whether there is available a potential consensus in support of such far-reaching transfers of competence from national to international institutions. This feature of the proposals also confronts directly the wellknown Soviet antipathy to the supranational administration of international agreements. One wonders, therefore, both from the perspective of domestic acceptance and international negotiability whether this insistence upon supranational judicial machinery is warranted. 
even more unlikely that either major nuclear power would accept the simple method of unilateral disarmament, even if such voluntary and unsupervised activity were to be mutually undertaken. This course is advocated by some Western civilian groups seeking thereby to circumvent the impasse at the conference table. There is no perceived disposition on the part of mankind, despite an occasional historical example to the contrary, to rely upon techniques of self-denial and self-imposed limitations in order to reassure or convince a potential enemy of peaceful intentions. Initiative of this type seems also to ignore the recent lesson on the hazards of appeasement: for to the extent that the Western democracies sought to convince Hitler of their commitment to peaceful relations, they tended to accelerate and abet his aggressive designs. With this experience vividly in mind there is no serious inclination in the West to end the arms race and possibly the cold war by the unilateral adoption of policies of conciliation.

On the contrary, prevailing elites accept the need to negotiate from a position of superior strength. This line of response, already deeply engrained in human tradition and recently reaffirmed by the failure of inter-war policies of appeasement, makes approaches to peace unrealistic, from the perspective of domestic politics, that do not rest upon programs based on complete and explicit mutuality. 27

The prospects for phased disarmament and individual arms control arrangements are also rather disappointing. A piecemeal approach to disarmament encounters the problems of differential utility in all of their paralyzing complexity. Almost any particular proposal bears unequally upon the military security of various national actors. It is almost impossible to negotiate mutual restrictions that are, and are perceived to be, equivalent. Geographical, manpower, strategic, fiscal, psychological, paramilitary, and intelligence variables have significantly different weights and characteristics for the two biggest nuclear nations. ${ }^{28}$ Even assuming a willingness to negotiate in good faith, these differences create enormous difficulties in the search for enough common ground to support a specific arms control or disarmament proposal.

27. For cogent arguments that there is much to be done between the extremes of unilateralism and a comprehensive disarmament treaty, see ETzIONI, THE HARD WAY to Peace (1962); and Osgood, An Alternative to War or Surrender (1962). There is an essential distinction between these authors who argue in behalf of certain unilateral initiatives designed to improve the negotiating atmosphere for a transition based upon mutuality, and those authors who advocate a unilateral program that is carried forward without regard for the responses of other nations.

28. Does "inspection" serve to deter and identify noncompliance, to protect participants against the dangers of surprise attack, or to gather targeting information for a counterforce attack? An absence of consensus about the functions of an inspection system helps to account for disagreement at Geneva (between governments) and at Washington (within our own) about how much inspection is needed at various stages of disarmament. See generally Verification Response in Disarmament Agreements (Woods Hole Study), November, 1962. 
The problem of differential utilities is aggravated, of course, by the prevailing patterns of distrust, hostility, and conflict that we group together for convenience by reference to a "cold war." In practical terms this means that disarmament negotiations involve hostile bargaining situations in which the participants are unsatisfied with any agreement that does not strengthen their relative military position in the cold war. Therefore, the disarmament situation is one in which the nuclear powers seek to gain relative military advantages in exchange for reducing or stabilizing absolute military potentials. It is thus prudence, rather than paranoia or insincerity which leads disarmament negotiators to suspect any agreement that is acceptable to the other side. If we add this bargaining incentive to the factual intractability of differential utilities, then frustrating and repeated stalemates are predictable, almost unavoidable, outcomes in the current world, especially when the stakes are as high as they are in the disarmament context.

In addition, an arms control or disarmament agreement must generate a powerful domestic consensus, especially in the United States. Even beyond the already formidable two-thirds requirement for the ratification of a treaty by the Senate, lurks the fear that a treaty signed with apparent legislative support might later generate enough opposition to block its ratification. This would do grave damage to the image of the United States in world affairs and might virtually preclude serious disarmament talks for a considerable period of years. An administration would be prudently reluctant, then, to accept a treaty at the signatory stage unless it could anticipate a firm $80 \%$ level of legislative support. This surplus of support beyond the constitutional minimum would somewhat insulate the agreement from intervening domestic pressures that might diminish the support that appeared available at the signatory stage. Comparable difficulties of generating domestic and intra-bloc political support also seem to interfere with attempts by the Soviet Union to negotiate toward mutually acceptable arrangements.

This high level of difficulty is reached without even questioning the good faith of the nations professing a commitment to disarmament. And, unhappily, serious grounds do exist for questioning the reality of even this minimal assumption. From the Soviet side, disarmament, once operational, might appear to make it much harder to change the external political status quo through support of wars of national liberation and instigation of subversive movements. The Soviet system, apparently, continues to be actuated by dynamic revolutionary energy that leads it to assume a missionary role in world affairs. The use of force has been essential for the transmission of revolutionary energy across national boundaries by the Sino-Soviet powers in the past.20

29. Cf. KardelJ, Soctalism and War: A Survey of Chrnese Critictsar of the Poltcy of Coexistence (1960); Aron, The Century of Total War (1954); Kintuer \& Kornfeder, The New Frontier of War (1962). But see Khrushchev, On Peaceful Co-Existence, 38 Foretgn AFFaIrs 1 (1959), where the notion of peaceful competition is advanced in terms that do not rely upon the use of force to expand one system's ideological base of power either within or between nations. Other formulations, however, stress the 
Without the possibility of direct and indirect military intervention, the political balance shifts in favor of the capability of domestic governments to mobilize the force that they need to maintain internal control.

Another and more sinister way to understand Soviet disarmament policy is that it may be used as nothing but an instrument of propaganda for appeal to the non-aligned nations and to peace groups throughout the NATO countries. Communist leaders have on past occasions manifested a willingness to exploit peace issues to promote partisan political objectives without any acceptance of the substantive goals advocated. Thus, for instance, the advocacy of disarmament and peaceful coexistence may seek primarily to weaken Western alliance and undermine domestic support for anti-Communist governmental policies, especially those concerned with the defense effort. At the same time Communist nations would strive to gain the decisive military upperhand in the arms competition as a prelude to further Sino-Soviet expansions. ${ }^{30}$ For the attainment of military superiority would facilitate expansion at the geo-political periphery of the Communist world by the subtle combination of infiltrations, probes and blackmail. These tactics have already been employed with considerable success during the Krushchev era of Soviet foreign policy. A change in the military balance would improve greatly the chances for a total Communist victory without seriously increasing the risks of destructive warfare. It thus opens up a relatively safe path leading to global domination. From this perspective, the function of disarmament negotiations is to confuse and weaken the West and to maintain the tolerance and sympathy of Afro-Asian states. There is no intention to promote a seriously entertained substantive objective.

Some experts are also suspicious of the Soviet advocacy of disarmament because disarmament would almost certainly require an opening of Soviet society. According to this view, the whole controversy about inspection is properly understood as an expression of the persisting refusal by the Soviet Union to risk any dilution of the sovereign control exercised by bloc governments over territory and people. The administration of a disarmament arrangement of any significance would undoubtedly include, if it were to be acceptable to the West, a considerable amount of intrusion by an international inspectorate upon the territory and affairs of participating states. The administration of disarmament, at least in its more advanced stages, almost certainly would require the International Disarmament Organization to perform what amounts to governmental acts in the course of supervising disarmament. Such a claim of co-sovereignty does appear to contradict the dependence of totalitarian

continuing use of force in just wars of national liberation to promote inter-national Communist objectives. See, e.g., Program of the Communist Party of the Soviet Union, adopted at the 22nd Congress of the CPSU, 48-55, Crosscurrent Press (1961).

30. But see Blackett, Steps Tozvard Disarmament, Scientific American, April 1962, p. 45. This would make it difficult to incorporate duties into the domestic law requiring citizens to report instances of non-compliance to the International Disarmament Organization. For such a duty gives the supranational organ a claim of allegiance that is paramount to that of national institutions. 
societies upon the maintenance of absolute control over the loyalties of the inhabitants. Thus it is the specific nature of the Communist system, as a domestic political order, that makes it difficult to conceive Soviet leaders accepting a disarmament proposal that contains sufficient apparatus to assure adequate compliance.

The sum of disadvantages of disarmament for the Communist nations seems rather substantial. However, these disadvantages should be balanced against the benefits that would result from the reduced prospect of nuclear war and from the relief that would come with the reduction of defense budgets. It is difficult to assess with any confidence Soviet attempts to reconcile these conflicting sets of considerations. There is probably considerable disagreement and ambivalence among Soviet leaders, as well as a tendency to shape policy in reaction to prevailing interpretations of Western disarmament strategy, intentions, and capabilities.

The West, too, appears to have an ambivalent attitude toward disarmament. In addition to the various problems of vested interests with respect to the defense budget, there are the perceived and real dangers of precipitating an economic depression or producing severe economic dislocations in the course of implementing disarmament. ${ }^{31}$ Furthermore, many important people in the West construe the Marxist goals of world domination quite literally and regard deterrent military strength as the main protection of the democratic West against continuing Communist encroachment. As well, there are some who regard our anti-totalitarian ideology as an affirmative mission that itself depends for success upon the availability of superior military strength. Thus, if it is the task of the West to recover enough dynamism to liberate people from Communism, especially those living in Eastern Europe, it is essential to use force or its credible threat. This argument is ideologically less rigorous, but similar in motivation and structure, to the inverse position taken by the Chinese Communists. Both ends of the ideological spectrum conceive political destiny in either/or terms, leading finally to a total victory for one side or the other.

In addition, the momentum of disarmament would be more difficult to reverse in democratic societies. That is, Sino-Soviet rearmament capabilities would give them an implicit bargaining and intimidation advantage in a disarming world. It seems plausible to suppose that a planned and controlled economy can make more effective and less disruptive transitions from and to defense production. Such a prospect has many multilateral ramifications, the impact upon the effectiveness of the NATO alliance being among the most significant and obvious. The Western democracies have already in this century suffered from the momentum of a disarmament-oriented system and they are

31. Cf. Benoit, The Economic Impact of Disarmament in the Unitcd Statcs, in Drsarmament: Its Poutucs and Economics 134-76 (Melman ed. 1962); Raymond, Problems of Industrial Conversion; Economic and Social Consequences of Disarmament: Report of the United Nations Secretary-General Transmitting the Study of His Consultive Group, id. at 332-96. 
chary of adopting such an orientation so long as powerful aggressor states exist.

It should also be appreciated that no feasible inspection system gives much promise of detecting significant non-compliance by a potential aggressor in the final stages of a disarming world. ${ }^{32}$ This is especially so if the potential violations might be the illicit production of biological and chemical weapons.

These considerations suggest that prospects for general and complete disarmament are not sanguine. Pursuit of this goal is, therefore, unrealistic and even dysfunctional, especially if it involves a tendency to deprecate more modest transition ventures.

This conclusion is not significantly weakened by the recent limited test ban treaty. There can be no doubt that the treaty has great potential significance as a symbol of transition. ${ }^{33}$ But from a technical point of view it does not do much to enhance the prospect of world peace. As Secretary Rusk has said, "All that it does is to eliminate testing in the atmosphere, in outer space, and under the water. It does not reduce nuclear stockpiles. It does not eliminate nuclear war or the threat of nuclear war. It does not prevent an arms race."34 In fact, it may allow subsequent weapon development to benefit from underground testing. Further, the treaty came at a time when many weapons and strategy experts were dubious about the value of subsequent testing, even if it were permissible. Hence, the treaty might be regarded as an instrument which formalizes what the parties would probably have done even in its absence. Finally, the partial test ban accord requires no special verification machinery. The exemption of underground testing is a significant indication of the limits of disarmament at the present stage of international relations.

32. The United States and the Soviet Union each advocate phased disarmament according to a three-stage plan. The Russian plan seeks to reach the terminal point of general and complete disarmament within four years. The United States starts slowly, $30 \%$ in Stage I, one half of the remaining armaments in Stage II, and final reductions to police levels in Stage III; also the process is to be carried on over a longer period of time. Stage I is expected to take three years, Stage II three years, and Stage III, "as promptly as possible within an agreed period of time." Therefore, although significant military capability will remain in existence in Stage III, the political system would have to have been considerably transformed to allow the prior reductions to take place.

33. President Kennedy expressed it well when he said that "Nuclear test ban negotiations have long been a symbol of East-West disagreement. If this treaty can also be a symbol-if it can symbolize the end of one era and the beginning of anotherif both sides can by this treaty gain confidence and experience in peaceful collaborationthen this short and simple treaty may well become an historic mark in man's age-old pursuit of peace." The attainment of accord on the partial ban was greeted with dramatic enthusiasm throughout most of the world. It signalizes the extent to which anti-war sentiments have penetrated human consciousness throughout the world, and are now available to insist upon and lend support to further disarmament efforts. Address by President Kennedy, The Nuclear Test Ban Treaty: A Step Toward Peace, 49 Dep'T State Bulr. 234, 236 (1963).

34. Mr. Rusk and Mr. Harrinan Discuss Nuclear Test Ban Treaty, 49 Dep't State BuLI. 240, 241 (1963). 
This skepticism about disarmament suggests that other responses to the transition question must be examined carefully. For history gives us no confidence that a balancing mechanism of the kind developed by deterrence strategy is capable of maintaining nuclear peace over a prolonged period of time. The existing system of international relations, even if it is rather stable, is intolerably dangerous because of the grave consequences that would attend a single failure at the strategic level in "the peace system" now relied upon.

Therefore, we regard it as essential, in view of the clouded prospects for substantial disarmament, to consider alternative or complementary transition strategies. It is in this light that we advance the proposal for international solution of domestic problems in pre-violent stages. Since this proposal is based in part on an interpretation of the legislative quality of recent General Assembly practice, the legislative character of certain types of UN activity must be explicated. A warless world would have to find peaceful substitutes for the legislative role that force and war have played in the history of international relations. We look upon the General Assembly as developing the tradition and competence to supply this need for legislation not only with respect to the control of domestic violence threatening serious international impacts, already an accepted function, but with respect, as well, to the settlement of domestic social problems that threaten to generate domestic violence if left unsettled.

\section{A Proposal for Extension of the Legislative Competence of INTERNATIONAL ORganizations.}

Despite the pessimistic outlook for disarmament, the international situation is not necessarily inhospitable to collective political action designed to reduce the potentiality for destruction. We have witnessed a certain amount of community effort to persuade the big nations to end the arms race and negotiate their differences. General Assembly resolutions condemning United States and Soviet nuclear test explosions should be understood, at least in part, as the expression of a judgment premised on the vital need to reduce the level of cold war tension.

It is true that many situations with potential for contributing to that tension are now more or less beyond the reach of the United Nations, as a consequence of the national attitudes which support the rule in article 2, paragraph 7 , forbidding the organization to intervene in matters essentially within the domestic jurisdiction. ${ }^{35}$ Even if, as is highly unlikely, the restriction of article

35. The exact wording of Article $2(7)$ is as follows: "Nothing contained in the present Charter shall authorize the United Nations to intervene in matters which are essentially within the domestic jurisdiction of any state or shall require the Members to submit such matters to settlement under the present Charter; but this principle shall not prejudice the application of enforcement measures under Chapter VII." The wording of this provision strengthens the argument for using the term "intervention" to describe interference undertaken by the United Nations. There are advantages that come from maintaining an identity between Charter terminology and scholarly commentary. 
2 (7) was removed as a formal barrier, there is little evidence, as yet, of a disposition to entrust the United Nations with much authority to impose a community solution upon an internal conflict unless that conflict produces sustained domestic violence and intense international concern. On the other hand, UN practice discloses a willingness to disregard the constraints of 2 (7) whenever an ardent consensus can be mobilized in the General Assembly. This is a fruitful area for reflection. For if techniques could be developed to allow the United Nations to practice precautionary intervention to solve festering social problems in non-bloc nations, then it might be useful in gradually modifying the belligerent stances assumed by the main nuclear rivals. Solutions "from above" offer a spectrum of unexplored techniques for arousing national sentiments that are inclined to favor policies that will not tempt "the enemy" to push the nuclear attack button.

Baldly stated, the proposal of this article is that if a situation exists within a domestic society which involves a severe denial of human rights, according to standards that are formally accepted by the overwhelming majority of states, and that society is located outside Soviet and American spheres of dominance, ${ }^{36}$ then the world community acting through the United Nations should seek to impose a solution by a graduated scale of supranational coercion. ${ }^{37}$ This proposal entails action by the United Nations to prevent the escalation of domestic social problems into cold war crises by intervening in domestic arenas with gradually increasing coercion, as soon as a supporting consensus can be reached. The proposal entails an expanded scope for United Nations competence in that it would create a duty obliging the United Nations to intervene whenever domestic social problems appear to two-thirds of the membership to provide the occasion for local protest movements successfully to solicit military involvement on the part of third states.

The presence of social problems is directly relevant to the discovery of an eventual solution for the transition problem. The argument that underlies this conclusion can be stated in summary form. Internal instability often arises when the discrepancy between the subjective expectations and objective fulfillment grows large in the new states. Awareness of the discrepancy engenders internal protest that often grows into violent opposition if the prevailing governmental elite refuses or is unable to meet the demands for social change at the proper rate. To make the protesting faction politically effective it is

36. The notion of "dominance" is a relative and variable one. In this context it refers to all of Europe and Latin America possibly North Africa, parts of the Middle East, possibly India, and all countries outside of Europe that are in the Communist camp. Sphere "outside," then refers to the Afro-Asian uncommitted states. We take issue with the idea that a state must take sides in the cold war and maintain that those states that remain outside of the cold war may provide the best situations for supranational coercion.

37. There is a direct correlation between domestic repression and international aggression that makes a severe domestic suppression of human rights a threat to international peace. Therefore, precautionary intervention can be vindicated as a peace-keeping measure. The facts in context make such an undertaking more or less persuasive. 
helpful, if "not necessary, to seek external help. The socialist bloc, especially if the appeal comes from regions that were formerly colonized, is responsive to such an appeal. To counteract this influence the West may give its support to incumbent regimes. These offsetting interventions bring the cold war into domestic politics, and produce intense, if limited, belligerent operations. Once the stage of belligerency is reached it is difficult to arrive at a satisfactory domestic resolution. It is characteristic of contemporary warfare that violence is unable to resolve conflict between great powers in any definitive sense. In fact, military violence leads to armistices rather than genuine peace treaties. This pattern of local stalemate imitates and is occasioned by the over-arching nuclear stalemate. Neither bloc, as a rule, obtains for itself or tolerates for its rival either a complete victory or defeat. The Korean War is a tragic paradigm.

In designing a rational taxonomy for social problems falling within this proposal certain distinctions should be taken into account. These distinctions do no more than refine the awareness of a social problem as a source of widespread discontent. It is useful to distinguish between the delineation of a social problem that is given by a participant from that given by an observer. There is a difference between the role and character of social problems in democratic and totalitarian societies. There is also a difference in role, character, and mode of response between social problems arising in mature, industrialized societies, and those arising in newly developing societies or relatively backward societies. Finally there is a crucial distinction between those social problems that do and those that do not bear upon the perceived issues of the cold war rivalry.

We must explain the requirement that the domestic arena chosen for intervention be external to the spheres of bloc dominance. It derives from the fact that a situation with high escalation potential is produced whenever the threat or the reality of a radical disaffiliation from bloc membership occurs. The escalation process is accelerated as soon as the bloc leader uses coercion to discourage or encourage disaffiliation. It is further aggravated in the event that rival cold war intervention in support of either faction take place. The process may continue, as it has in Cuba, in the post-disaffiliation stage in order to retard or punish anew affiliation within the rival bloc. The Western Allies might have given material aid to help the Hungarian revoluton in 1956 or the Soviet Union might today urge and assist a Cuban armed attack against Guantanamo. It is evident that a flock of influential hawks is readily available in either major power center to demand such action. Nevertheless, the decision in both of these instances has been not to engage in provocative activity-because both elite groups acknowledge and defer to the dominant position of the other in this area. ${ }^{38}$

38. It is difficult to interpret events in Cuba in the light of this ordering principle. However, if one regards the failure of the invasion of 1961 at the Bay of Pigs as the end of the disaffiliation phase, then subsequent participation by the Soviet Union is consistent with superpower deference to intra-bloc interference. 
This reciprocal deference to spheres of influence has some effects which are not pleasant for either side. Their acceptance of it, however, is based on a combination of limited capabilities and the normative logic of reciprocity. Major states are aware that any serious deviation from the present structure of reciprocity might produce severe and destabilizing retaliations that hardly seem worth the intrusion, even if successful. This situation is conducive to the formation of conditions of minimum stability. Its existence, in turn, depends partly upon the advocacy of restraint and the assertion of conscience by individuals and groups within the nation but outside the formal organization of power and authority. Certainly this form of stability would deteriorate if either bloc were to meddle or intervene by giving a secondary member of the rival bloc substantial miltiary aid so as to encourage it to extend deviant behavior to a point of violent disaffiliation. Certain types of behavior by one bloc in the primary sphere of the other remain permissible. Substantial economic and military post-deviation aid to Yugoslavia by the United States or by the Soviet Union to Cuba have been tolerated. However, adventuresome intervention policy within the sphere-of-influence of the other major power is and should be realistically constrained by a sharp awareness of the dangers of escalation. ${ }^{39}$

The world community, acting through the United Nations, has had little success in intervening in matters of violent intra-bloc conflict. The resolutions and action of the organization were not susceptible to adequate implementation precisely because the facts of bloc dominance, considering the meagerness of available supranational military capabilities, made it futile to claim supranational control over the outcome of intra-bloc warfare. So long as the relative power of the UN is so small, an overwhelming consensus of the world community must exist if one expects the United Nations to act properly or effectively. At this stage, it is imperative that the United Nations refrain from the assertion of claims, the effect of which would be to disturb patterns of mutual understanding that introduce some stability into cold war competition. Upsetting patterns of bloc coherence is much more likely to precipitate a major disaster than is the continuation of open conflicts taking place within non-aligned nations where cold war competition is mutually tolerated by the blocs themselves as an aspect of the prevailing mode for both the use and constraint of violence in the course of political competition.

An example may help to make the proposal of this article more concrete. The Congo situation was of dimensions sufficiently limited to comply with our requirements for intervention. An analysis of it may help, in general, to identify those unsolved social problems where a formal UN commitment is feasible and where effective curative action, if properly designed, might prove acceptable to both power blocs.

39. For an interesting normative account of these patterns of reciprocal deference see McIVhinney, Suziet and Western International Law and the Cold War in the Era of Bipolarity, 1 CAN. Y.B. Int'l LAW 40, 75-81 (1963). 
The Congolese were organized by native groups who felt that Western imperialism was evil and moribund. Hence, they demanded their freedom and independence from the Belgian government. Not only did the Belgian government lack the support of significant portions of its own citizenry for continuing the colonial status of the Congo but its colonial policy was opposed by many of its allies, the Afro-Asian nations and the socialist bloc. In the face of this rising tide of opposition, Belgium suddenly acquiesced to the demands for independence by announcing that it would transfer full sovereignty to a new Congo state administered by native leadership. The transfer took place on schedule, but severe conflict emerged among internal claimants. The character of Congolese authority and power was in issue. This produced an outbreak of civil strife emanating from several nativist centers of aspiration.

Such domestic instability frequently attends a drastic change in the political status of a community. This is especially so in a community that has not regularly experienced changes, as contending factions perceive the fluidity of the period of changeover as a final opportunity to seize power before the new regime is able to restabilize fully its control. In the Congo these rival claims were of a character that stimulated cold war antagonists to interfere in the new state (to some extent by invitation) by a variety of techniques: advice, technical assistance, diplomatic missions and military equipment. In addition to the big powers, strong Belgian, British, and Katanganese capital interests were attempting to shape the new independent Congo. It was under these circumstances that Patrice Lumumba, the legitimate head of state and the most popular claimant to the transferred authority, appealed to the Security Council for assistance. Lumumba requested that the United Nations expel foreign mercenaries who were characterized as Belgian aggressors and quell the secessionist movement in Katanga. The Security Council responded affirmatively and passed various enabling resolutions insisting that all agents of foreign governments who had become involved in Congolese strife halt their activities and, in some cases, leave the country. In addition, the Security Council established a United Nations force to help achieve order in the Congo and to perform normal governmental services. Provisionally, it can be said that despite internal and international obstacles ${ }^{40}$ and a serious lack of adequate manpower for the tasks undertaken, the United Nations, as an organization, has been able to operate as the chief stabilizing element in a situation that has been otherwise highly disorderly, as well as periodically

40. There was an interaction between internal and international obstacles in the Congo. The internal situation was dominated by a factional struggle for power between rightist and leftist groups, between antagonistic personalities, and between hostile tribes. This encourages international rivals and diverse political orientations to seek an outcome within the Congo that would give political control to a sympathetic elite. Whatever choice the United Nations made, it was necessarily alienating some important nations eager to combine UN presence with a resolution of the civil war that was favorable to their interests. For full account, see Burns \& Heathcote, Peace-Keeprng ay U.N. Forces from Suez to the Congo (1963). 
dangerous and destructive. Serious social problems-starvation, disease, unemployment, genocide, breakdowns of authority relations-existed at the time of intervention and remain somewhat unresolved. The urgency of these problems made it rational to assume some risks that seemed to increase the likelihood of thermonuclear war, the very kind of risks that should not be normally incurred or tolerated. ${ }^{41}$ In most situations though, the overriding policy objective normally should be to avoid thermonuclear war, even if such a commitment may involve sacrificing other values and policies. Only an exceptional series of threats to human values may justify a particular decision to increase the dangers of escalation. Nevertheless, in the Congo situation UN intervention furthered the policy of war avoidance through the reduction of escalation dangers and the implementation of the kinds of anticipatory action that attempted to ameliorate, if not solve, a social problem before it emerged as a cold war crisis.

The elements of "the intervention" by the United Nations in the Congo are significant. First, the United Nations was initially invited, in fact, urged to intervene by the state in question. The importance of an "invitation" has been emphasized, to date, in peace-keeping operations. It has been absent, to the chagrin of the colonialist states and the Republic of South Africa, in cases where the organization's "intervention" has stopped short of -the use of force in its narrow military sense. Secondly, an initial unanimity was present among the "veto" powers in the Security Council. Thirdly, the intervention was expressed in semi-humanitarian terminology; the problem was not defined by explicit reference to either chapter VI or chapter VII. ${ }^{42}$ It was not approached as application of a Charter provision. Rather, it was treated as the grant of assistance to a former colony that was experiencing serious difficulties in its attempts to cut the last strands that bound it to a colonial power. It was thus a matter of helping this new nation to achieve economic viability and political stability. Fourth, there was ardent support given by most of the sub-Sahara African members of the United Nations. This support was expressed by the participation of regional personnel in the military and policy-making phases of the operation. Fifth, resources existed to make it plausible to suppose that the claim asserted by the United Nations on behalf of the world community could be effectively carried out, even in

41. These polar valuations operate in this essay on a candidly hortatory basis. There is a need to find operationally relevant criteria, e.g., the refusal to threaten nuclear force to attain any political objective.

42. Chapter VI of the United Nations Charter, comprising Articles 33-38, specifies the capacity of the Security Council and the General Assembly to work for the pacific settlement of disputes between states; most of Chapter VI deals with the role of the Security Council which is given the major responsibility for pacific settlement. Chapter VII, Articles 39-51, is entitled "Action with Respect to Threats to the Peace, Breaches of the Peace, and Acts of Aggression," outlines the competence of the Security Council to engage in peace-keeping activities. Enforcement, as distinct from persuasion, is supposed to be carried on by the Security Council in accord with the provisions found in Chapter VII. 
the face of maximum opposition from certain quarters. These five considerations-invitation by the constituted government of the strife-torn state, initial unanimity among the "veto" powers, a convincing humanitarian rationale, regional participation, and the prospect of effective assertion-provide a set of criteria that is, in the abstract at least, descriptive of UN practice and of the preferences of most of its membership.

In the peace-keeping situation the presence of an invitation to intervene by the constituted government is a significant, although not all-disclosing factor. To the extent that "intervention" precludes votes of censure and recommendations that members break diplomatic relations or apply economic sanctions, action without an invitation has been a standard attribute of United Nations practice. Such "uninvited intervention" was most recently manifested in the action taken by the organization with respect to Angola and the Republic of South Africa. ${ }^{43}$ There is an important distinction between the relevance of an invitation to a peace-keeping operation, especially in the context of a civil war in which an incumbent government with international status exists, and its irrelevance to action undertaken against an "evil" government, a government that is found to have committed aggression or has been declared guilty of flagrant abuse of human rights. The two contexts may considerably overlap in the event that a civil war breaks out in Angola, Rhodesia, or South Africa.

On the other hand, there have also been significant instances in which invitations to intervene have been received and the United Nations has failed or refused to act.4 In many of these situations, the intervention was to have been predicated upon an application of chapter VI or chapter VII of the Charter. These situations called for either the threat to use substantial force against a nation that was powerful within the theater of conflict or required the organization to act against the Soviet Union or the United States in a crisis situation located within a state that was a firm bloc member of one or the other of these two dominant powers (e.g., Hungary in 1956). The organization is too weak in independent strength and political will to act effectively in either type of situation.

Stated more positively, the Congo situation suggests that an invitation by a non-bloc state to handle a major social problem within its borders, or an invitation, the acceptance of which can be explained on humanitarian grounds, presents the kind of situation in which a United Nations intervention is often already feasible and can be made more so. It is important to suggest that the social problems which are most relevant to this form of idealized interaction between a nation and an international organization are those around which local social protest movements can organize their claims for

43. Earlier instances involve Portugese control of $\mathrm{Goa}$, the domestic political conditions in Spain, and the Dutch withdrawal from Indonesia. 63).

44. E.g., Hyderabad (1954), Guatemala (1954), Hungary (1956), and Cuba (1962- 
support. Some social problems are being handled adequately by the technical agencies of the United Nations in a relatively depoliticized atmosphere that is uncontaminated by the cold war. When the organization is able to deal with social problems on this basis, then it is possible to emphasize solutions and to subordinate politics. In contrast to the characteristically unpolitical conduct of many of the technical agencies is the highly political behavior of the organization whenever a social problem has been perceived and debated in cold war terms with blocs proposing and demanding lines of solution that contradict one another. This kind of controversy is not likely to induce effective action by the Security Council for it will be disadvantageous for one side to permit international intervention to establish the solution of the other side. The paralysis that follows when issues are absorbed into the cold war makes it desirable for the non-aligned states to take the lead by identifying problems deserving the attention of the organization when it appears likely that the problems will be otherwise drawn into the cold war struggle if allowed to smoulder unregulated.

A widespread international consensus is also important for the workability of this article's proposal. Intervention has already become a major politicallegal undertaking of the United Nations. But the pre-Congo experiences and the Congo situation itself confirm the impression that the United Nations is most effective when supported by an overwhelming, cold war-transcending consensus as was mobilized in whole or part during the operations of the organization in Indonesia, Israel, Korea, and Suez. In contrast, the United Nations has been ineffective when this consensus has been absent, as was the case in Algeria, Hungary, and Tibet. The organization tends to work effectively whenever the crucial members are committed to a similar although not identical, attitude toward the proper disposition of a dispute. The prior establishment of intervention as an effective UN tool does not, however, trivialize the contribution of this article's proposal for intervention in previolent stages. For, part of the strategy underlying this proposal is to devise a way of dealing with issues by consensus which, if their internationalization is postponed, will probably be dealt with later on as an aspect of cold war conflict. That is, the creation of a United Nations responsibility for the solution of domestic social problems is a technique for enlarging the operative scope of international consensus. If this can be done, with even modest success, it might change considerably the image that each side has of the other by bringing to light those things about which all major states can agree. This will correct the impressions gained by a concentration, so exclusive as to be almost obsessive, by cold war rivals upon issues of discord and dissensus. Thus it would be a significant contribution both to solving the transition problem and safeguarding peace in the existing system of international relations if the United Nations can reflect a cooperative approach to a domestic problem, which, if allowed to remain unattended, would generate insurgent violence that could be transposed into an occasion for cold war confrontation. 
A third characteristic of the proposal is the stress it lays on the relation between the promotion of human rights and the preservation of international peace. Thus, the United Nations should not usually help an "evil" incumbent government suppress domestic social protest, even if the insurgency receives some foreign encouragement and support. In fact, by allowing its machinery to be used for a set of actions that ascend from discussion through censure to diplomatic and economic sanctions and, finally, to military sanctions, the United Nations puts itself gradually in the position of legitimizing domestic insurgency. It is not the elimination of domestic violence that will help safeguard the peace, but the cause of peace can be helped by the prior satisfaction of grievances that can find no other solution but violence. Timing is exceedingly important-to intervene before the domestic conflict has been polarized along cold war lines and to coerce a solution that expresses a non-political judgment based upon the universal commitment to the equality of people regardless of race, nationality, gender, or religion. Fostering these goals may occasion violence in certain societies, say Southern Rhodesia or the Republic of South Africa. But this proposal assumes that violence sponsored by the organized community will, in general, although not in each particular case, be less dangerous than allowing the domestic conflict to run its natural course, often culminating in insurgent recourse to protracted violence and terror abetted by foreign intervention. ${ }^{45}$ However desirable the potential of UN intervention into domestic problems at pre-violent stages may be, the success of this proposal requires the serious acceptance of an extension of function and competence of some UN agency. This extension can be achieved by a variety of methods. One approach is to revise the Charter. This is so hard to accomplish that it can be dismissed as politically unattractive. Another mode of extension is the gradual evolution of practice by deliberate interpretations of the existing mandate to act. A third mode of extension relies on developing further trends already revealed in the practice of the General Assembly. ${ }^{46}$ This third approach would seem to have great merit. To begin with, no potential vote is involved. Furthermore, the General As-

45. It should be noted that a distinction exists between the relevance of nuclear war to unsolved domestic social problems for which the United Nations intervention is recommended and political violence that is carried on across international boundaries. For social problems it may be necessary to initiate violence with a low escalation potential so as to cut down on the prospect of subsequent intrastate violence with an increased escalation potential. This is the basis for recommending coercive intervention in the affairs of Angola, Rhodesia, and the Republic of South Africa. In contrast, if the violence is of interstate proportions then the escalation factor is already too high and the United Nations should be used, to the extent that it is politically possible to help the victim state restore the status quo ante. Nuclear peace and the frustration of aggression remain dominant ordering considerations. A full argument is made in FALK, LAW, WAR, AND Morality in the Contemporary WORLd 42-65 (1963).

46. This interpretation of practice is also supported, although indirectly and not unambiguously, by the view of the majority in the advisory opinion of the International Court of Justice in the case of Certain Expenses of United Nations, [1962] I.C.J. Rep. 151, 163-75 (advisory opinion). 
sembly, since it operates in certain respects as a legislative body, would be a natural place in which to experiment with a proposal which makes an attempt to extend the legislative reach of the United Nations. There are, however, disadvantages. Since the Charter seems to restrict its function to the making of recommendations, any assumption of legislative power by the General Assembly rests on shaky foundations. True, if there is a sufficient consensus behind a General Assembly recommendation, its decision begins to embody the qualities of legislation. Indeed, that has been the tone of General Assembly practice in recent years. Nevertheless, despite the growth in practice of General Assembly power, charter limitations hamper the explicit assumption of the legislative competence required for the implementation of this article's proposal. Even UN interventionary claims made so far have encouraged an attitude of disrespect for the Charter as the organic law of that organization and have deprived minority members of juridical protection. It may be possible eventually to use the broader, more constitutionally based authority of the Security Council, at least when a consensus among the veto powers exists. However, despite its drawbacks as a political institution, the General Assembly contains the only real legislative constituency-the Afro-Asian bloc-in the organization. One must conclude that the Assembly has the more genuine basis for and tradition of rendering world community judgments. A wide endorsement from the Assembly of a United Nations intervention more probably assures continuing political support for the organization's activities than does a show of temporary unity in the Security Council.

\section{AN Assessment}

Beginning with a recognition of the difficulties that attend the effort to establish a stable peace system for the conduct of international relations, this article has tried to develop a proposal that will contribute partially and indirectly to the solution of the transition problem. This proposal argues for the gradual expansion of the legislative functions ${ }^{47}$ assumed by international

47. The emphasis of this proposal is upon the creation of an effective legislative competence for the United Nations in the social policy field. It is legislative in the sense that it enables a consensus of the General Assembly to undertake a program of social and political change in a state, thereby altering its domestic legal order. It is not legislative in the sense of generating new fundamental norms, but it is legislative to the degree that it creates norms intermediate between the broad Charter directives (Preamble, Articles 1,2, and 55) and the specific policy that is to be executed in a particular situation (e.g., decolonialization, racial equality). There is an ad hoc quality to this variety of legislative activity, for we have in mind a series of intermediate norms developed to meet a series of domestic situations rather than the enactment of "a law" that can be used by executive officers (the Secretariat) to handle all recurring problems in the area. The notion of legislation, like the idea of law itself, should not be transferred from the domestic political environment without due regard for the distinctive character of the United Nations. Our proposal constitutes our understanding of the functional character of "legislation" in the United Nations context. For a preliminary attempt to develop these ideas see Falk, The Legitimacy of Legislative Intervention by the United Nations, in Essays on Intervention and International Law (to be published by the Ohio State University Press). 
institutions organized on a regional and global basis. It encourages international organizations, subject to limitations and safeguards, to intervene in domestic conflicts that have assumed or threatened to assume violent proportions.

The proposal arises in the first instance from the plausibility that a nuclear war will escalate out of a local conflict and from the tendency of cold war rivals to commit themselves to securing sympathetic resolution of domestic struggles for national dominance. The United Nations has received from its members a particularly broad grant of authority to do what is necessary to maintain international peace and security. This mandate takes precedence over all complementary policies and rules, and especially the policy against displacing the norms of domestic jurisdiction which exist to insulate national realms of activity from outside interference. Stated in simplest form, the proposal is a proposition: whenever peace is endangered, United Nations intervention is justified. As such, this is a commonplace. The novelty of the proposal is its broader view of danger to international peace-that domestic social problems, even at a previolence stage, are a sufficient danger to international peace to warrant United Nations intervention, whether or not this intervention requires a disregard of traditional sovereign prerogatives. There is little doubt that if this proposal achieves any operational significance in the practice of the United Nations, it will be a radical, if somewhat disguised step toward world government. For the consequence is to centralize governing competence for the formation of controversial domestic policy in international institutions. This involves a considerable reallocation of competence and authority between national and supranational decision-makers that might have a significant influence upon the willingness of elites to substitute for exclusive national values and goals those of a genuine world commuunity.

There are, however, several shortcomings of an approach to international order that relies upon legislative intervention by supranational institutions. First of all, there is the danger that a moral solution proposed outside the relevant national community will harden patterns of adherence within the community. Certainly this seems to have been the case in South Africa and Angola. The long struggle of the South against the grant of real equality to the Negro is also partly a refusal to accept a solution devised by and dictated from the North. Moral revitalization depends ultimately upon the processes of inner transformation. It is this style of argument that seems to be such a persuasive rebuff to those who wish to roll back forcibly the Communist empire to the boundaries of the Soviet Union. It is also the most promising mode of liberalization for the various Communist regimes. There are severe dangers of a moral variety that attend any undertaking that depends upon an external coercive animus. However, these dangers must be viewed in the tragic context of choice, itself heavily conditioned by the paramount need to reduce the dangers of war, strife and unrest.

Second, there are serious questions of feasibility. We are proposing cooperative action on matters of crucial political and social concern by national 
rivals that are deeply divided as to the proper way for the world to be run and organized. Non-bloc participants are often bloodthirsty, irresponsible, and highly provincial in outlook. Their outlook is conditioned by a very oldfashioned pursuit of national interests and not by a sense of a moral mission to build a community. Furthermore, serious abuses of human rights and fundamental problems of social discontent exist within the Sino-Soviet bloc. These must be systematically overlooked, at least to the extent that a UN response requires censure of and coercion against the existing regimes.

Intra-bloc problems can not often be usefully raised on a supranational level at this stage. The political motivation is too high and the prospects for a meaningful supranational response are almost nil. Even so, the debates on Hungary and Cuba in the United Nations may have served as marginal restraints upon policymakers in the United States and the Soviet Union, leading to the eventual adoption of a moderate course. Supranational consensus is not easy to form with respect even to situations outside the blocs. Even if agreement exists on the highest level of abstraction, it often disappears when it comes to devising a scheme for implementation. Competing national and ideological perspectives present themselves when implementation issues are raised. The Congo operation discloses the extent to which common objectives do not assure the presence of a common interest to sustain their attainment. There are various ways to topple colonialism. The United States prefers the emergence of a moderate, democratically inclined government, affiliated with the West, and tender toward its past. The Sino-Soviets prefer, more or less, the obverse. If we qualify the proposal by requirements of incumbent consent and inter-bloc consensus, then it may not often prove feasible to agree on the standard that should govern specific supranational interventions.

Third, the principles that support supranational intervention by global or quasi-universal institutions are much more problematic with respect to regional intervention. Often regional communities act to discourage or penalize heterogeneous political developments. One thinks of the regional pressure available to coerce Israel, Formosa, and Cuba. In each instance what is incompatible with the regional consensus is compatible with the minimum requirements for participation in a universal organization; this contrasts somewhat with the relevance of regional pressure against the Republic of South Africa, which is confirmed by a global consensus.

Fourth, a proposal of this sort requires states to subordinate national perspectives to the desiderata of world community welfare. This is somewhat utopian as long as international organizations are predominantly perceived as institutions that are useful means to reach national ends. Members are not significantly free to adopt an outlook and program that is an optimal community response to social problems.

Despite these substantial obstacles, our conclusion is that the advocacy of increasing legislative competence for supranational, especially universal, institutions is beneficial. It promotes a recognition of the connection between 
an international welfare system and the transition to a warless world. This kind of awareness might help to generate the kind of expectations that would support our objective of moving beyond a primary reliance upon the nation for security and welfare. It is high time that we confront their rationality of an inertial approach to world order with a radical rationality more appropriate to the urgencies of the age. This proposal is submitted as a hesitant first step to find the obscure path of radical rationality. 